\title{
The Contribution of Traditional Ecological Knowledge and Practices to Forest Management: The Case of Northeast Asia
}

\author{
Seongjun Kim, Guanlin Li and Yowhan Son * \\ Department of Environmental Science and Ecological Engineering, Korea University, Seoul 02841, Korea; \\ dao1129@hanmail.net (S.K.); jlmeys@naver.com (G.L.) \\ * Correspondence: yson@korea.ac.kr; Tel.: +82-10-3290-3015
}

Received: 9 November 2017; Accepted: 8 December 2017; Published: 12 December 2017

\begin{abstract}
This study aims to introduce the potential applicability of traditional ecological knowledge and community forestry in Northeast Asia, including China, Japan, and South Korea. In ancient Northeast Asia, forest policies and practices were based on Fengshui (an old Chinese concept regarding the flow of vital forces), with which forests were managed under community forestry. However, these traditional systems diminished in the twentieth century owing to the decline of traditional livelihood systems and extreme deforestation. Recently, legacies from traditional ecological knowledge and community forestry have been revisited and incorporated into forest policies, laws, and management practices because of growing needs for sustainable forest use in China, Japan, and Korea. This reevaluation of traditional ecological knowledge and community forestry has provided empirical data to help improve forestry systems. Although traditional ecological knowledge and community forestry in Northeast Asia have been scarcely theorized, they play a significant role in modifying forest management practices in the face of socioeconomic changes.
\end{abstract}

Keywords: community forestry; forest history; forest management practice; traditional knowledge

\section{Introduction}

The presence of a relationship between traditional ecological knowledge and forest management practices is undeniable [1]. Traditional ecological knowledge implies legacies inherited across thousands of years of interaction between humans and their surroundings [2], which were used to develop forest management practices in ancient societies [3,4]. Although much of the traditional knowledge and many practices have faded owing to the broad use of modern forestry systems, legacies remain in current societies, with which the applicability of traditional ecological knowledge can be piloted [5]. This contributes to enhancing the understanding of socioeconomic systems and forest ecosystems [6,7], and encourages research that focuses on traditional ecological knowledge in terms of forest management [8,9]. Therefore, many countries have acknowledged the importance of traditional ecological knowledge for forest management [10,11].

China, Japan, and South Korea in Northeast Asia are characterized by a long history of forest management. Ancient Northeast Asian societies relied on forests for timber, fuel, and resources for agriculture, and considered forests to be vital and holy places [12]. This importance of forests forced ancient societies to develop diverse forest policies and practices to foster forest resources. For example, documents have been found reporting afforestation activities, forest resource monitoring, pest control activities, and pruning works in Korea in the third, eighth, fourteenth, and eighteenth centuries, respectively (Table 1). Other records indicating long histories of forest management have also been found in China and Japan [3,4]. 
Table 1. Major forest management policies and practices of the ancient Korean kingdoms [13-16].

\begin{tabular}{cc}
\hline Century & Policies and Practices \\
\hline Third & Pinus densiflora Sieb. and Zucc. afforestation near royal tombs and palaces \\
Eighth & Afforestation and replanting of Pinus koraiensis Sieb. and Zucc., Juglans mandshurica Maxim., \\
and Morus alba L. & Castanea spp. and Pyrus spp. orchard establishment \\
Tenth & Law defining punishiment aginst ilegal logging and forest fire setting in Pinus densiflora forests \\
Fifteenth & Law establishing locally specialized offices for selecting plantation species according to economic \\
Fifteenth & values and local environments \\
Seventeenth & Promotion of community forestry groups for patrolling local Pinus densiflora forests \\
Eighteenth & Encouragement of pruning activities of Pinus densiflora seedlings \\
Nineteenth & Promotion of land clearing and weeding activities in young Pinus densiflora plantations \\
\hline
\end{tabular}

In the twentieth century, Northeast Asia faced rapid socioeconomic changes accompanied by forest transitions. The economies of China and Japan grew rapidly, and the demand for timber and charcoal grew as well. Accordingly, forests in China were frequently overexploited beyond the allowable quotas as a result of economic growth-oriented development $[17,18]$. Although forests in Japan were relatively well preserved, many naturally regenerated forests were replaced by monoculture plantations for timber or other land use types $[9,19]$. South Korea experienced severe deforestation during the same period, owing to Japanese colonization and the Korean War [20]. However, the national forest restoration programs in South Korea successfully restored forest ecosystems with liberalization of timber imports and substitution of energy sources [21].

Because China, Japan, and South Korea have successfully fostered the nations' forest resources in contrast to the other Northeast Asian countries [22], the case of the three countries could be helpful to improve the sustainability of the forestry sector [19]. Nonetheless, current forestry systems rarely integrate knowledge from these countries because of the poor understanding of the legacies from traditional ecological knowledge and practices in ancient Northeast Asian societies. Limitations in the historical, quantitative data in this region further hinder assessment of the applicability of traditional ecological knowledge and practices for the forestry sector and the actual use of the legacies accordingly [7].

The current study aims to provide an overview of the potential applicability of traditional ecological knowledge and practices, especially community forestry, related to forest management in Northeast Asia. Specifically, we explore traditional knowledge and practices in ancient Northeast Asia, and the legacies from the traditions that remain in modern China, Japan, and South Korea. Due to the limited availability of historical data, quantitative approaches were not used for this objective.

\section{Traditional Ecological Knowledge and Practices in Ancient Northeast Asia}

\subsection{The Fengshui Concept within Forestry}

Ancient societies in Northeast Asia dealt with local socioeconomic conditions and natural environments managed on the basis of vast experience and old beliefs. Fengshui (an old Chinese concept concerned with the flow of vital forces and substances across a landscape) was one of them. Whether Fengshui entails an understanding of natural phenomena remains a topic of debate because its rationale and reliability have been scientifically untested [23,24]. Nonetheless, it is important to note that this concept, as part of traditional ecological knowledge, affected forest management practices in ancient Northeast Asia $[3,25,26]$. The issues regarding Fengshui itself were not addressed, in order to focus on its relationship to ancient Northeast Asian forestry.

According to original Chinese traditions, the main focus of Fengshui was land planning and management through harmonizing human settlement with all of its natural surroundings [12]. As one way to achieve harmonization, the Fengshui concept specified the optimal location for afforestation. The basic afforestation strategy was to locate human settlements on sites surrounded by mountains 
and hills, and to fill up the bare "entrances" and "backyards" of the settlement through afforesting them [23]. Such forests were believed to improve the landscape by adjusting the flow of vital forces and substances [4,23]. Afforested lands were regarded as holy, religious, and even scary places according to Fengshui. Consequently, Fengshui acted as a cultural background to foster and protect local forests for the villagers, and helped in the acquisition of forest products in ancient Chinese society [27]. This attitude to forests based on Fengshui migrated to other countries, such as Japan and Korea, and influenced forest management practices in those countries as well [7].

Fengshui-based forestry in ancient Northeast Asia was adjusted to local experience and knowledge on topography, climate, and tree species. Ancient villagers living on riversides changed the basic afforestation strategy to prevent flooding and soil erosion by planting water-tolerant tree species between the village and river [26]. In coastal areas, they altered the strategy to establish windbreak forests, consisting of salt-tolerant species such as Pinus thunbergii Parl., alongside the sea coast [28]. It was also applied to more practical forest management purposes than the original land planning and management concepts. One significant example of the practical Fengshui application was the community forest (afforested lands near villages shared for various purposes by the villagers). Community forests, such as Fengshui forests in China, Satoyama (village mountains) in Japan, and Maeulsoop (village groves) in Korea, were widespread in ancient Northeast Asia because of the common cultural afforestation practiced on the basis of Fengshui [7]. These forests allowed water, organic matter, and nutrients to circulate between the forests, croplands, and village, as they connected these natural and anthropogenic components according to Fengshui [4,29] (Figure 1). Therefore, community forests in Northeast Asia were important for the livelihoods of ancient society, such as the supply of timber, fuel, fodder, and compost for agriculture and residence [4,30].

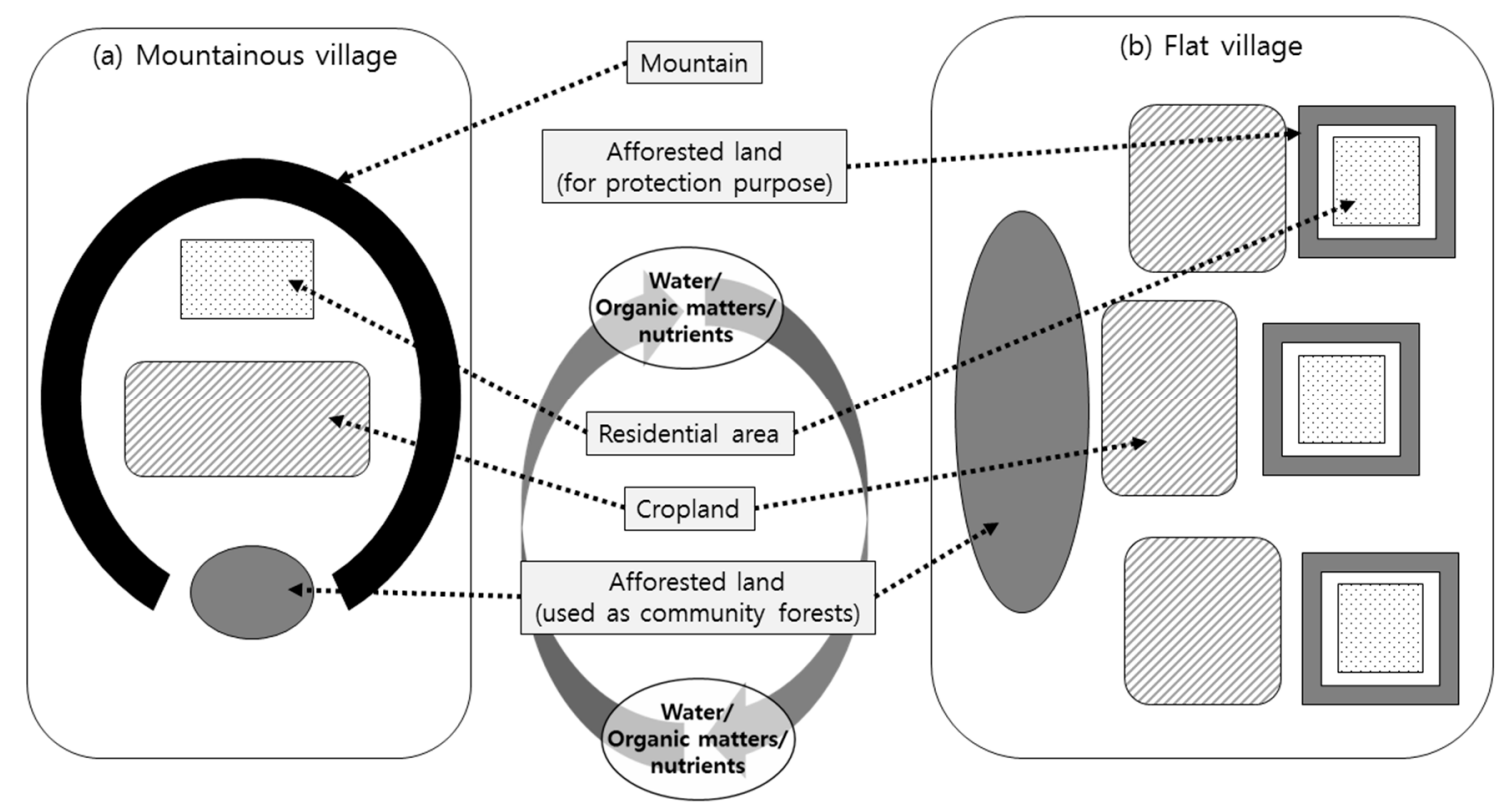

Figure 1. Types of the traditional community forests based on Fengshui in Northeast Asia (modification of the conceptual figures in $[4,30])$.

Community forests based on Fengshui were also implemented to protect both natural environments and human settlement (Figure 2). Some community forests on the mountain behind villages fulfilled this role by reducing soil erosion and landslide from steep slopes [3,19]. Like Satoyama-implemented for protection purposes in Japan-and "Bibo" (help and improvement) forests in Korea, the forests for such protective purposes enclosed houses, villages, or coastlines [25,31,32]. These forests were important for livelihoods in ancient Northeast Asia because they controlled village microclimates by preventing flooding [3,26], acting as windbreaks [25,28,31], and connecting forest patches [32,33]. 


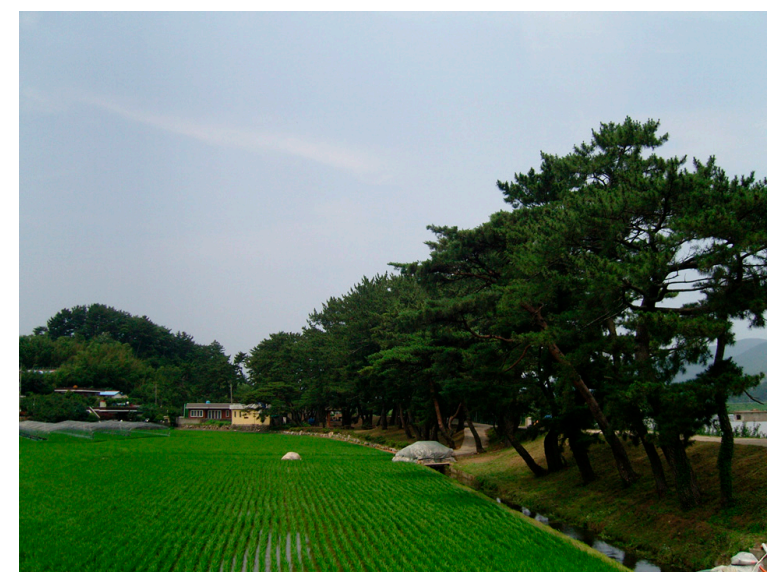

Figure 2. A community forest in Gwangyang, South Korea. The forest is located near croplands and residential area to prevent strong wind and flooding.

\subsection{The Historical Forest Policies and Practices}

Many old records show that ancient kingdoms in Northeast Asia may have established diverse forestry policies and laws based on their experience and knowledge. For example, ancient policies and laws specified the way to manage forests in accordance with the characteristics of tree species and the site conditions. In ancient China, fast-growing water-tolerant species such as Salix spp. were afforested on hill slopes near rivers to prevent flooding and landslide in the tenth century [3]. Although naturally regenerated oak forests were widespread in Japanese Satoyama, Pinus densiflora Sieb. and Zucc., trees were instead selected in dry and infertile conditions $[9,10]$. In the seventeenth century, Cryptomeria japonica D. Don, Chamaecyparis obtusa Sieb. and Zucc., and Pinus densiflora trees were recommended in Japan for plantations in moist valleys, on mountainsides, and on dry mountain ridges, respectively, according to these species' tolerance to dry conditions [14,34]. In addition, an ancient Korean kingdom in the fifteenth century had a law establishing locally specialized offices, which selected the plantation species in accordance with the local environmental conditions and the value of each species [15]. This ancient Korean kingdom planted Pinus densiflora trees in dry and infertile areas in the fifteenth century as this species is more tolerant to water and nutrient shortages than competitive broadleaf trees [35]. This kingdom also applied intensive forest management practices, such as land clearing, weeding, and pruning practices, to young Pinus densiflora plantations in the eighteenth and nineteenth centuries according to the growth characteristics of Pinus densiflora [28].

Ancient kingdoms also concentrated on forest protection, by considering the productive and protective functions of forests $[13,24]$. One ancient Chinese kingdom had a law defining allowable periods for fire setting for slash and burn farming to reduce hazardous forest fire in the eleventh century [3]. Between the fifteenth and twentieth centuries, an ancient Korean kingdom politically protected Pinus densiflora, and did not permit private logging in selected lands, especially those containing mature Pinus densiflora forests such as "Geumsan" or "Bongsan" (forbidden mountains) [14]. Because government did not have enough labor to protect all forbidden forests from illegal logging and poaching, the ancient kingdom needed to cooperate with local groups. This situation forced the kingdom to strengthen the authority of local groups for self-organization and punishment [16], and resulted in the reinforcement of community forestry systems by villagers (see below).

\subsection{Community Forestry}

Forestry in ancient Northeast Asia featured community forestry systems for managing and utilizing the shared forests afforested according to the concept of Fengshui. Because community forests were important in terms of religion and livelihood, local groups attempted to sustain them by sheltering them from natural and anthropogenic disturbances [36]. Local groups established self-regulatory rules 
for community forests defining the permitted ways of wood harvesting, duties of forest patrols, and even stricter punishment for illegal forest use than government laws [4,13]. As local villagers mostly provided the labor for implementing government policies and laws (see Table 1 and Section 2.2), traditional community forestry was important for silviculture as well [35].

In China, there were local groups, such as Cuiguimingyue (village regulation and customary law) in Guizhou Province, that were oriented specifically to forestry [7]. Local villagers organized Cuiguimingyue by themselves, and developed rules to sustain local forest resources and conserve forests for symbolic and religious purposes [27]. This local group attempted to protect community forests through prohibiting logging of old trees, fuelwood collection from other villager's private forests, and setting forest fires [37]. Cuiguimingyue immediately punished villagers who violated the regulations protecting the forests, as government officers had no capacity to monitor these issues arising in the individual villages [27].

Rural villagers in Japan also shared resources from local forests. Villagers cooperated to collect wood for fuel, charcoal, and construction, and to protect local forest resources from overexploitation $[19,30]$. This form of local groups also dealt with post harvesting forest regeneration, mainly by coppicing of hardwood species [10]. The local groups in Japan focused on the collaboration of forestry and agriculture. Villagers collected fallen leaves and twigs as compost to fertilize cropland soils, and strengthened the community agreement by regulating the allowable period and amount of compost harvesting [30,38].

In Korea, Songgye (private Pinus densiflora cooperative) operated as a local pine forestry cooperative from at least the seventeenth century to the early twentieth century because of the ancient Korean kingdom's Pinus densiflora conservation policy (Table 1) [13]. Although Songgye originated from wood protection policies of the ancient Korean kingdom for government uses, it also acted as a local group for community forestry [13,39]. The primary objective of this group was to patrol local Pinus densiflora forests and issue fines for illegal logging of Pinus densiflora, thus protecting the forests from natural and anthropogenic disturbances [36]. This local group contributed to constructing an emergency contact network for watching forest fires especially in dry seasons [13]. Members of Songgye often cooperated to construct and repair trails to Pinus densiflora forests near their village [40]. It also led the villagers to cooperate in wood collection and distribute the collected wood at low prices [13]. Although this form of local group is not currently active, such activities contributed to sustaining local pine forests and their associated livelihoods in ancient Korea [39].

\section{Implementation of Traditional Ecological Knowledge and Community Forestry in Modern China, Japan, and South Korea}

\subsection{China}

In the mid-twentieth century, the political priority of the Chinese government was to reconstruct the nation's economy, and overcome poverty and backwardness [17]. This growth-oriented economic policy elevated timber and charcoal use for construction and steel making, and promoted large-scale logging operations [41]. Such logging operations frequently resulted in timber overexploitation beyond the allowable quotas [18], and the destruction of the traditional Fengshui forests [27]. In addition to contributing to global climate change, this overexploitation of the forests has led to serious deforestation and desertification in China [41].

Since the mid-1980s, the Chinese government has been concentrating on forest protection through rehabilitating natural forests, afforesting marginal croplands, decelerating desertification, and establishing timber forests with low environmental impacts [41]. To reduce private forest overexploitation, the Chinese government attempted to revisit the applicability of Chinese community forestry traditions. In particular, the community forestry and forest protection cultures in the southern part of China were reconsidered as management alternatives for forestry and biodiversity conservation $[7,27,42]$. 
Anhui, Sichuan, and Yunnan Provinces have received model projects incorporating traditional community forestry [43]. These projects used local traditional ecological knowledge and practices to adjust modern knowledge and techniques to local environments. For example, such an approach has been piloted from the early twenty-first century in Yunnan Province, where villagers relied on the traditional shifting cultivation system, consisting of a short cropping phase and long forest fallowing phase [44-46]. In this region, traditional shifting cultivation was combined with the rotational tree planting and harvesting part of the modern forestry concept [46]. Project staff and workers asked farmers to share indigenous knowledge of native, economically valuable crops and tree species, and actively participate in selecting tree rotation age, monitoring pilot sites, and evaluating the piloted approach [44]. They have educated local farmers on how to establish local societies for community forestry, and provided alternative energy sources and energy saving techniques to prevent forest overexploitation [43]. Through these activities encouraging villagers' participation, modern knowledge and techniques (e.g., rotation age and species selection) have been further adjusted in the context of local traditional ecological knowledge and thus contributed to forest resource protection as well as local economy $[44,46]$. Accordingly, the model projects in Yunnan Province have provided information to reinforce the applicability of the traditions to the forestry sector.

China recently established and modified policies and laws to support governmental projects aiming at the protection and sustainable use of forest resources [43]. The Chinese government issued the modified version of the Forest Law of the People's Republic of China in 1998, which declares the rights of autonomy and economic benefit for ethnic minorities in the forestry sector in addition to the general principle for the nation's forestry [47]. It helps facilitate local villagers' participation in the protection of forests on the basis of their traditional ecological knowledge and practices, such as Cuiguimingyue [48]. Other policies and laws, such as the Law of the People's Republic of China on Land Contract in Rural Areas and the Collective Forest Tenure Reform, define rights and ways for villagers' participation in resolving conflicts and making decisions in relation to the management and use of forests $[43,45,48]$.

\subsection{Japan}

The post-war economic growth in Japan has revolutionized energy sources, chemical fertilizers, and building materials, and diminished the usefulness of the traditional Satoyama system for obtaining timber, fuelwood, charcoal, and compost [29]. Commercial monoculture plantations or urban areas replaced many natural forests, although forests in Japan were relatively well established $[9,49]$. However, inexpensive foreign timber imports and an aging rural population have reduced domestic timber production since the 1960s [34]; consequently, both traditional community forests and monoculture plantations were abandoned without taking into account public interests and appropriate management operations [19]. This forest underutilization has become a serious issue in Japan, as the structure of unmanaged forest can shade out understory vegetation and cause soil erosion and biodiversity loss $[7,30,50]$.

To tackle afforestation, traditional ecological knowledge and practices were used in terms of the selection of plantation species. Similar to the ancient kingdoms, plantation species selection in Japan was originally based on topography, climate, and soil properties as well as the characteristics of the tree species [15]. This species selection system was adjusted in the twentieth century with consideration given to profitability and manageability (such as pest tolerance) to relieve forest underutilization and abandonment [15].

Since the twentieth century, Japan has actively revisited traditional ecological knowledge and practices in terms of the sustainability of the forestry sector. The Japanese government has initiated projects targeting the harmonization of human society with nature and, since 1994, has identified the restoration of the traditional Satoyama system as an important strategy [9]. The applicability of the traditional community forestry system has been piloted at several prefectures including Okayama, Kanagawa, Kyoto, and Ishikawa to activate the management and use of abandoned community 
forests $[9,38]$. These projects have been combined with activities of local cooperatives to pilot traditional concepts and community forestry for diverse rural societies in mountainous, grassland, and suburban areas. In Ishikawa prefecture, the local government introduced Ishikawa Forest Environment Tax in 2006 and Satoyama Creation Fund in 2011, both of which aim to assist the restoration of the traditional satoyama landscape and management of abandoned plantations [51].

The Japanese government and the United Nations University jointly started the Satoyama Initiative at the Conference of the Parties (COP 10) in 2010. This initiative has promoted the reassessment of community forest traditions around the world, and attempted to integrate such traditions into modern forestry systems [10,29]. The concept of the Satoyama Initiative has migrated to other countries that share the community forestry tradition, and stimulated a reevaluation of traditional ecological knowledge and practices related to forests [10,52].

Monitoring studies have shown that the remaining Satoyama landscapes contribute to ecosystem functioning. Traditional coppicing in Satoyama has higher potential for carbon sequestration than modern forestry systems, consisting of intensive thinning activities [53]. Furthermore, high landscape connectivity among forests, croplands, and water sources within conserved Satoyama significantly served as sites for nesting and foraging of birds, such as Butastur indicus Gmelin [54]. Because of the high landscape connectivity, Satoyama also provides habitats for the entire lifecycle of insects, including Luciola cruciata Motschulsky, Ranatra chinensis Mayrt., and Apis cerana japonica Radoszkowski $[30,54,55]$. This reflects the potential negative impacts of the decline of Satoyama as a result of forest underutilization and urbanization on biodiversity and proper ecosystem functioning $[54,56]$.

\subsection{South Korea}

Japanese colonization and the Korean War extensively destroyed forests in the Korean peninsula until the mid-twentieth century [20,21] (Figure 3). The traditional Maeulsoop have declined because of colonization and warfare [13], and subsequent construction-oriented village development [28]. Accordingly, the traditional community forestry groups, such as Songgye, became obsolete [39]. The South Korean government has developed diverse forest restoration programs since the 1960s, including large-scale reforestation activities and nursery management combined with a substitution of energy sources from fuelwood to fossil fuel [21,57].
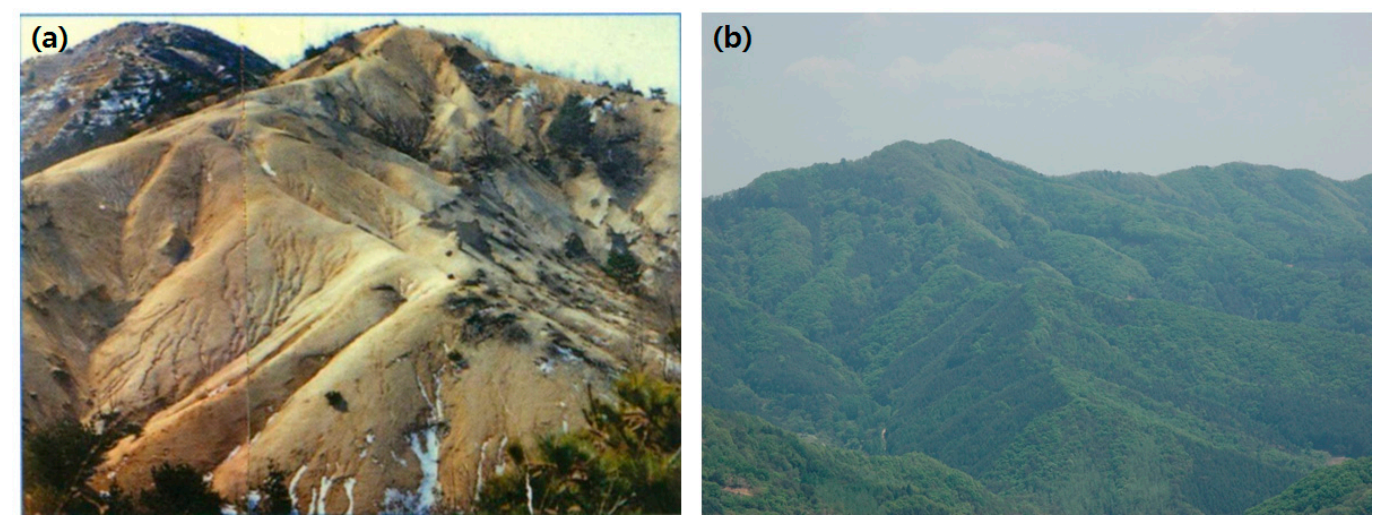

Figure 3. (a) Deforested lands in the mid-twentieth century (Photo from the Korea Forest Service) and (b) revegetated forests after the national forest restoration programs in South Korea.

The forest restoration programs utilized much traditional ecological knowledge and practices. Like the rules of the ancient kingdoms, the South Korean government listed the locally specialized plantation species taking into account climate, topography, and soil fertility after the national soil survey conducted during the 1970s [15]. The fast-growing or nitrogen-fixing species were recommended for degraded and infertile lands but more economically valuable species were selected 
for relatively fertile lands (Table 2). The government also adopted intensive weeding, pruning, and pest control practices from the ancient policies (Table 1), and widely applied such practices to the young plantations from 1973 to 1978 to increase the survival rate of planted seedlings [58]. The current South Korean forestry system has inherited these forest management practices and tree species selection concept [15].

Table 2. Plantation species for the national forest restoration programs of South Korea in the 1970s [15].

\begin{tabular}{|c|c|c|c|}
\hline Site Index * & $\begin{array}{c}\text { Cool Temperate Central } \\
\text { Region }\end{array}$ & $\begin{array}{c}\text { Cool Temperate Southern } \\
\text { Region }\end{array}$ & Warm Temperate Region \\
\hline (1) & $\begin{array}{l}\text { Larix kaempferi (Lamb.) Carr., } \\
\text { Castanea crenata Siebold \& } \\
\text { Zucc., Populus spp. }\end{array}$ & $\begin{array}{c}\text { Cryptomeria japonica D. Don, } \\
\text { Paulownia coreana Uyeki, } \\
\text { Castanea crenata }\end{array}$ & $\begin{array}{c}\text { Cryptomeria japonica, } \\
\text { Paulownia coreana, Castanea } \\
\text { crenata }\end{array}$ \\
\hline (2) & $\begin{array}{c}\text { Larix kaempferi, Castanea } \\
\text { crenata, Populus spp., } \\
\text { Pinus koraiensis }\end{array}$ & $\begin{array}{c}\text { Chamaecyparis obtusa Sieb. and } \\
\text { Zucc., Populus spp., } \\
\text { Castanea crenata }\end{array}$ & $\begin{array}{l}\text { Chamaecyparis obtusa, } \\
\text { Cryptomeria japonica, } \\
\text { Paulownia coreana }\end{array}$ \\
\hline (3) & $\begin{array}{c}\text { Populus spp., Pinus koraiensis, } \\
\text { Pinus thunbergii Parl., Robinia } \\
\text { pseudoacacia L. }\end{array}$ & $\begin{array}{c}\text { Populus spp., Pinus thunbergii, } \\
\text { Chamaecyparis obtusa, } \\
\text { Robinia pseudoacacia }\end{array}$ & $\begin{array}{c}\text { Pinus thunbergii, } \\
\text { Chamaecyparis obtusa }\end{array}$ \\
\hline (4) & $\begin{array}{l}\text { Pinus rigida Mill., } \\
\text { Pinus thunbergii, } \\
\text { Robinia pseudoacacia }\end{array}$ & $\begin{array}{c}\text { Pinus rigida, Pinus thunbergii, } \\
\text { Robinia pseudoacacia }\end{array}$ & $\begin{array}{l}\text { Pinus rigida, Pinus } \\
\text { thunbergii, Robinia } \\
\text { pseudoacacia }\end{array}$ \\
\hline (5) & $\begin{array}{l}\text { Alnus japonica (Thunb.) } \\
\text { Steud., Pinus rigida }\end{array}$ & Alnus japonica, Pinus rigida & Alnus japonica, Pinus rigida \\
\hline
\end{tabular}

Site Index * was based on topography (e.g., altitude, slope, and aspect) and physicochemical properties of soils (e.g., parent material, depth, texture, moisture, organic matter, and hardness).

The other important strategy originating from traditional ecological knowledge and practices of the ancient Korean kingdoms was the participation of the public in forest restoration programs. The South Korean government established a national tree planting period between 21 March and 20 April, to encourage public participation [20]. Since 1951, a local participatory group, Sallimgye (private forest cooperative), has been established under the government's policies and laws [59]. The structure and activity of Sallimgye were similar to those of the traditional Songgye in ancient Korea [60]. The group consisted of local villagers living near a target reforestation site, who primarily provided labor to carry out government reforestation activities. This local group led villagers' participation in seed collection, nursery operation, and forest patrol, while the allocated benefits from local forests, including fuelwood, timber, and fruit, went to the villagers [57].

The forest restoration program with traditional ecological knowledge and practices benefited livelihoods. Areas reforested with fast-growing trees (e.g., Robinia pseudoacacia L.) provided more than 29 million Mg of fuelwood for heating and cooking from 1973 to 1988, and those with Castanea crenata Sieb. and Zucc. produced 30 thousand Mg of chestnuts for consumption from 1976 to 1987 [57]. These forest products afforded additional energy and food sources to local people during that period [57]. Reforestation also contributed to the protection of residential and agricultural areas by reducing the risk of natural disasters, such as landslide and flooding [61].

After intensive economic growth and urbanization, raising awareness of sustainability and ecosystem services resulted in a reevaluation of traditional community forests. To confirm the value and applicability of traditional practices, empirical data from Songgye, including old documents and oral histories, have been collected and analyzed from the early twenty-first century [40]. The structure of Songgye in the twentieth century was analyzed to find factors leading to the decline of Songgye and assess the potential applicability of traditional community forestry in current societies [39]. In addition, ecological monitoring found that conservation of Maulsoop could be applicable to reduce wind speed and evaporation; contribute to water conservation during spring, a dry season of the 
Korean peninsula [31]; and protect plant diversity—one of the strategies for improving landscape connectivity [33].

Due to the reevaluation of traditional ecological knowledge and practices, the Korea Forest Service has restored more than 70 Maeulsoop since 2003, which are principally used for recreation, education, and tourism [62]. The restoration consists of not only reforesting degraded Maeulsoop, but also collecting diverse information including oral or documented history, area, ownership, and species composition of each Maeulsoop to modify restoration strategies according to natural and socioeconomic conditions [62]. A nongovernmental organization, Forest for Life, has collaborated with the Korea Forest Service and local committees to preserve the traditional Maeulsoop and surrounding landscape [63]. This organization has provided subsidies for the restoration of several Maeulsoop, such as Yondangsoop in Gyeonggi Province in 2005 [62], and has attended town meetings and workshops to exchange perspectives among participants concerning the restoration project [63].

\section{Implications}

Socioeconomic changes stimulated the implementation of traditional ecological knowledge and community forestry to improve forest management systems in China, Japan, and South Korea. Post-war economic growth in China and Japan accompanied forest overexploitation in China and forest underutilization in Japan (Figure 4). In South Korea, the national level of deforestation after colonization and warfare forced the country to develop strategies for restoring the nation's forest ecosystems (Figure 4). In the twentieth century, these changes acted as critical issues, to which previous forest management practices had to adapt.

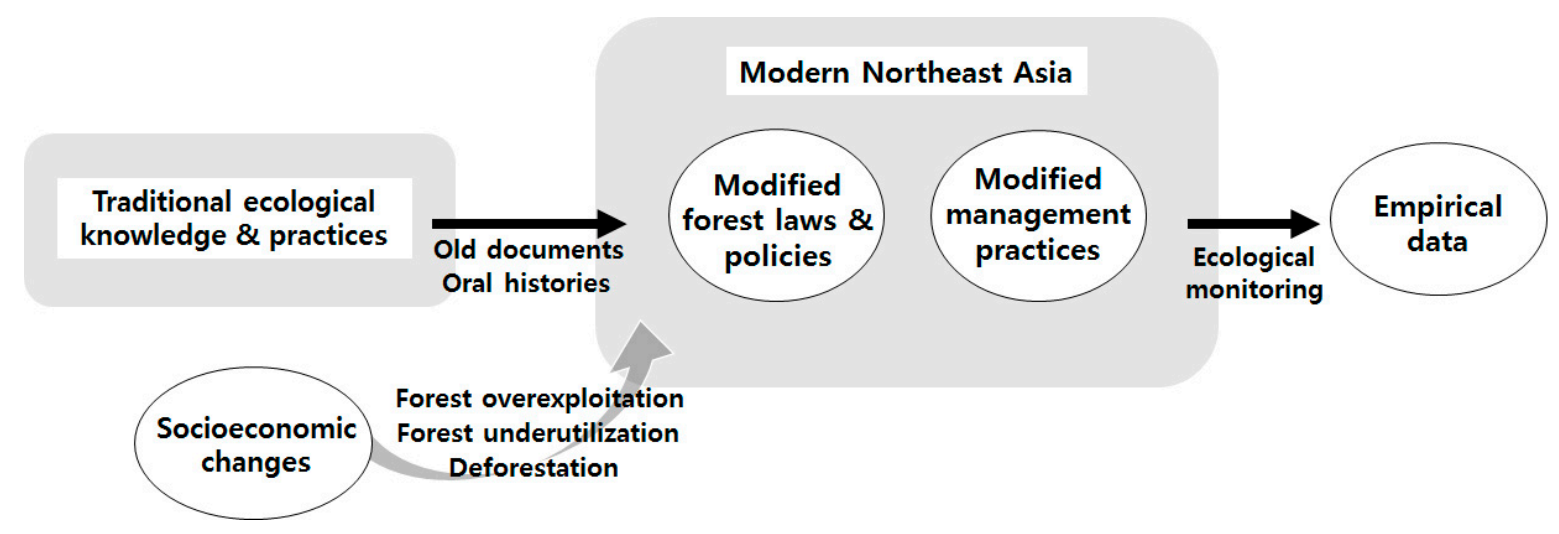

Figure 4. Role of traditional ecological knowledge within the forestry sector in modern Northeast Asia.

Given these changes, traditional ecological knowledge and practices were applied to adjust forest management practices (Figure 4). The Chinese government encouraged the community forestry tradition for the national cropland afforestation program [44,46]. Japan and South Korea implemented the old plantation species selection concept using environmental conditions to relieve forest underutilization and improve the forest restoration strategy [15]. Especially in South Korea, the national forest restoration programs used diverse traditions related to plantation species selection, intensive weeding and pruning practices, and community forestry in the mid-twentieth century $[16,58]$. For such applications, traditional ecological knowledge and practices tended to combine with modern knowledge of profitability and manageability or large-scale soil monitoring activities.

One important trend was that China, Japan, and South Korea reevaluated the applicability of the community forestry tradition for restoring and sustaining the nations' forests. The reevaluation included not only restoring community forests and traditional community forestry, but also installing political alternatives and paying subsidies to support the restoration. All three countries recently established laws and policies to promote public participation in forestry and the restoration of community forests $[38,48,60]$. With this political support, community forestry traditions have been 
implemented and have helped address forest overexploitation in China, forest underutilization in Japan, and deforestation in South Korea [9,54].

Monitoring of the pilot sites has provided empirical data that supports the importance of the contribution of traditional ecological knowledge and practices to the forestry sector (Figure 4). Monitoring studies have detected higher biodiversity and habitat connectivity in traditionally protected forests than in disturbed forests $[33,42,54]$. Such traditionally protected forests also appear to enhance village microclimates by controlling wind speed and air humidity [25,31]. The restored community forests have been used for recreation and environmental education concerning socioecological system resilience as well as biodiversity conservation $[7,30]$. The pilot projects have also contributed to resolving the loss of social connections and community forestry activities, left behind by the degradation of rural society $[9,37,62]$. These recent experiences demonstrate the importance of traditional ecological knowledge in the forestry sector [1].

Several factors aided in the implementation of traditional ecological knowledge and practices. A decentralized system played a role because it enabled villagers to directly distribute and benefit from the revisited traditional ecological knowledge and practices [9,57]. The partnership between the government and private sectors stimulated the establishment of the decentralized system, and technical and financial support for the projects $[51,62,64]$. Localizing modern techniques using traditional and indigenous knowledge also assisted the reevaluation and implementation of the traditional systems $[44,46]$. These implications may be helpful for the other Northeast Asian countries, which share a similar culture but suffer from severe loss of forest resources [22]. Particularly, the North Korean government has been promoting community forestry to overcome extreme deforestation, but it has not been scaled up to a national level owing to political, institutional, and financial constraints [65]. We suggest that the experiences of utilizing traditional ecological knowledge and practices in China, Japan, and South Korea are applicable to deal with the constraints hindering forest restoration projects in North Korea.

It is noteworthy that the recent implementation of traditional ecological knowledge in China, Japan, and South Korea is not a strict revival of traditions. The primary objective of projects applying traditional ecological knowledge and practices was the improvement of the local economy and forest resources $[64,66]$. Many restored community forests have been used for more practical purposes (e.g., education, recreation, and cultivation) than traditional ceremonial purposes [46,62]. This situation changed people's perspectives of traditional ecological knowledge and practices from old religious aspects to well-being, and led to the decline of several traditions that did not fit into such alteration [64]. Thus, the consequences of the reevaluation of traditional ecological knowledge and practices should be further assessed in the context of long-term socioeconomic changes.

Applying traditional ecological knowledge and practices to current forest management practices still remains challenging despite its benefits. Less intensive forestry systems based on the traditional concept might not be enough to substitute the modern forestry system, which has satisfied the demands for industrial and commercial forest products [67]. The traditional concept is limited to the pilot level due to the lack of scientific understanding on the link between traditional ecological knowledge and the socioecological system resilience [7]. These issues should be thoroughly considered before applications of the traditional concept at broader scales. However, the previous trends in China, Japan, and South Korea reflect the importance of traditional ecological knowledge and practices-incorporated into modern forestry systems-in the face of socioeconomic changes to date.

\section{Conclusions}

Traditional ecological knowledge and practices in Northeast Asia, consisting of the Fengshui concept, historical experiences, and community forestry systems, have established a way of managing and using forest resources in ancient Northeast Asia. These traditional systems had declined in the twentieth century owing to a decreasing demand for the traditional livelihood systems. Key concepts of traditional ecological knowledge and practices were recently revived and combined with forest 
management practices in the face of current socioeconomic changes in this region. The empirical data from monitoring such activities supported the development of forest management alternatives with traditional ecological knowledge and practices. Before implementing traditional ecological knowledge and practices beyond the pilot level, several challenges should be overcome: the results of revisiting traditional ecological knowledge and practices should be clarified along with the long-term socioeconomic changes; the interaction between traditional ecological knowledge and socioecological system resilience should be scientifically understood. However, the reevaluation of traditional ecological knowledge in China, Japan, and South Korea will be useful to overcome constraints hindering forest restoration in the other Northeast Asian countries.

Acknowledgments: The present study was supported by the Korea Forest Service (S211216L030120), the Ministry of Environment of Korea (2014001310008), and a Korea University Grant in 2017. We thank Hiroyuki Muraoka of the Gifu University in Japan for his helpful comments during the manuscript preparation.

Author Contributions: S.K. and Y.S. conceived the key concept of the paper. S.K. wrote the paper and led the data collection and review. G.L. and Y.S. contributed to the data collection and review.

Conflicts of Interest: The authors declare no conflict of interest. The funder played no role in the process of the current study.

\section{References}

1. Berkes, F.; Colding, J.; Folke, C. Rediscovery of traditional ecological knowledge as adaptive management. Ecol. Appl. 2000, 10, 1251-1262. [CrossRef]

2. Berkes, F. Traditional ecological knowledge in perspective. In Traditional Ecological Knowledge: Concepts and Cases; Inglis, J.T., Ed.; International Program on Traditional Ecological Knowledge, International Development Research Centre: Ottawa, ON, Canada, 1993; pp. 1-9, ISBN 1-895926-00-9.

3. Guan, C. Study on knowledge and practice on function of conserving water and soil of forests in ancient China. Sci. Soil Water Conserv. 2004, 2, 105-110. (In Chinese)

4. Youn, Y.-C.; Liu, J.; Sakuma, D.; Kim, K.; Masahiro, I.; Shin, J.-H.; Yuan, J. Northeast Asia. In Traditional Forest-Related Knowledge; Parrotta, J.A., Trosper, R.L., Eds.; Springer: Dordrecht, The Netherlands, 2012; pp. 281-313, ISBN 978-94-007-2143-2.

5. Park, H.; Lee, J.Y.; Song, M. Scientific activities responsible for successful forest greening in Korea. For. Sci. Technol. 2017, 13, 1-8. [CrossRef]

6. Bürgi, F.; Gimmi, U.; Stuber, M. Assessing traditional knowledge on forest uses to understand forest ecosystem dynamics. For. Ecol. Manag. 2013, 289, 115-122. [CrossRef]

7. Lee, E.; Krasny, M.E. Adaptive capacity in community forest management: A systematic review of studies in East Asia. Environ. Manag. 2017, 59, 34-49. [CrossRef] [PubMed]

8. Ramakrishnan, P.S. Traditional forest knowledge and sustainable forestry: A north-east India perspective. For. Ecol. Manag. 2007, 249, 91-99. [CrossRef]

9. Watanabe, T.; Okuyama, M.; Fukamachi, K. A review of Japan's environmental policies for Satoyama and Satoumi landscape restoration. Glob. Environ. Res. 2012, 16, 125-135. [CrossRef]

10. Berglund, B.E.; Kitagawa, J.; Lagerås, P.; Nakamura, K.; Sasaki, N.; Yasuda, Y. Traditional farming landscapes for sustaining living in Scandinavia and Japan: Global revival through the Satoyama Initiative. Ambio 2014, 43, 559-578. [CrossRef] [PubMed]

11. Herrmann, T.M.; Torri, M.-C. Changing forest conservation and management paradigms: Traditional ecological knowledge systems and sustainable forestry: Perspectives from Chile and India. Int. J. Sustain. Dev. World Ecol. 2009, 16, 392-403. [CrossRef]

12. Coggins, C.; Chevrier, J.; Dwyer, M.; Longway, L.; Xu, L.; Tiso, P.; Li, Z. Village Fengshui forests of southern China: Culture, history, and conservation status. Asia Netw. Exch. 2012, 19, 52-67. [CrossRef]

13. Chun, Y.W.; Tak, K.-I. Songgye, a traditional knowledge system for sustainable forest management in Choson dynasty of Korea. For. Ecol. Manag. 2009, 257, 2022-2026. [CrossRef]

14. Kong, W.-S.; Lee, S.H.; Bang, J.-Y.; Hong, S.-C.; Choi, S.-K. The History of Korean Forests; The Society for Forests and Culture: Seoul, Korea, 2014; pp. 134-185, ISBN 978-89-93453-21-8. (In Korean) 
15. Korea Forest Research Institute. History of the Tree Selection System and Its Application; Korea Forest Research Institute: Seoul, Korea, 2009; pp. 7-73, ISBN 978-89-8176-543-9. (In Korean)

16. Kwon, S.-K. An analysis of Bongsan policy in the late era of Chosun dynasty. Korean Policy Sci. Rev. 2007, 11, 81-104. (In Korean)

17. Dai, L.; Zhao, W.; Shao, G.; Lewis, B.J.; Yu, D.; Zhou, L.; Zhou, W. The progress and challenges in sustainable forestry development in China. Int. J. Sustain. Dev. World Ecol. 2013, 20, 394-403. [CrossRef]

18. Xu, J.; Tao, R.; Amacher, G.S. An empirical analysis of China's state-owned forests. For. Policy Econ. 2004, 6, 379-390. [CrossRef]

19. Takeuchi, K.; Ichikawa, K.; Elmqvist, T. Satoyama landscape as social-ecological system: Historical changes and future perspective. Curr. Opin. Environ. Sustain. 2016, 19, 30-39. [CrossRef]

20. Tak, K.; Chun, Y.; Wood, P.M. The South Korean forest dilemma. Int. For. Rev. 2007, 9, 548-557. [CrossRef]

21. Bae, J.S.; Joo, R.W.; Kim, Y.-S. Forest transition in South Korea: Reality, path and drivers. Land Use Policy 2012, 29, 198-207. [CrossRef]

22. Fang, J.; Guo, Z.; Hu, H.; Kato, T.; Muraoka, H.; Son, Y. Forest biomass carbon sinks in East Asia, with special reference to the relative contributions of forest expansion and forest growth. Glob. Chang. Biol. 2014, 2019-2030. [CrossRef] [PubMed]

23. Han, K.-T. Traditional Chinese site selection-Fang Shui: An evolutionary/ecological perspective. J. Cult. Geogr. 2001, 19, 75-96. [CrossRef]

24. Wu, Y.-B. Origin of Fengshui woods and its enlightenment to modern society. J. Landsc. Res. 2011, 3, 96-99.

25. Chen, B.; Nakama, Y.; Kurima, G. Layout and composition of house-embracing trees in an island Feng shui village in Okinawa, Japan. Urban For. Urban Green. 2008, 7, 53-61. [CrossRef]

26. Whang, B.-C.; Lee, M.W. Landscape ecology planning principles in Korean Feng-shui, Bi-bo woodlands and ponds. Landsc. Ecol. Eng. 2006, 2, 147-162. [CrossRef]

27. Yuan, J.; Liu, J. Fengshui forest management by the Buyi ethnic minority in China. For. Ecol. Manag. 2009, 257, 2002-2009. [CrossRef]

28. Park, J.-C. Concept and case of village grove. Keimyung Korean Stud. J. 2006, 33, 233-262. (In Korean)

29. Takeuchi, K. Rebuilding the relationship between people and nature: The Satoyama Initiative. Ecol. Res. 2010, 25, 891-897. [CrossRef]

30. Miyaura, T. Satoyama-A place for preservation of biodiversity and environmental education. Die Bodenkultur 2009, 60, 23-29.

31. Koh, I.; Kim, S.; Lee, D. Effects of Bibosoop plantation on wind speed, humidity, and evaporation in a traditional agricultural landscape of Korea: Field measurements and modeling. Agric. Ecosyst. Environ. 2010, 135, 294-303. [CrossRef]

32. Lee, K.-S. Bee-bo forest: Traditional landscape ecological forest in Korea. In Landscape Ecological Applications in Man-Influenced Areas: Linking Man and Nature Systems; Hong, S.-K., Nakagoshi, N., Morimoto, Y., Eds.; Springer: Dordecht, The Netherlands, 2008; pp. 389-394, ISBN 978-1-4020-5487-7.

33. Koh, I.; Reineking, B.; Park, C.-R.; Lee, D. Dispersal potential mediates effects of local and landscape factors on plant species richness in Maeulsoop forests of Korea. J. Veg. Sci. 2015, 26, 631-642. [CrossRef]

34. Iwamoto, J. The development of Japanese forestry. In Forestry and the Forest Industry in Japan; Iwai, Y., Ed.; University of British Columbia Press: Vancouver, BC, Canada, 2002; pp. 3-9, ISBN 0-7748-0882-9.

35. Han, J.-S. The development of forests and the formation of policy for cultivating pine trees in the period from Taejo to Sejong of Joseon. Sahak Yonku 2013, 111, 42-81. (In Korean)

36. Gillett, P.L. The village gilds of old Korea. Trans. Korea Branch R. Asiat. Soc. 1913, 4, 13-44.

37. Yuan, J.; Wu, Q.; Liu, J. Understanding indigenous knowledge in sustainable management of natural resources in China: Taking two villages from Guizhou Proince as a case. For. Policy Econ. 2012, 22, 47-52. [CrossRef]

38. Hasegawa, M.; Pulhin, J.M.; Inoue, M. Facing the challenge of social forestry in Japan: The case of reviving harmonious coexistence between forest and people in Okayama prefecture. Small-Scale For. 2013, 12, 257-275. [CrossRef]

39. Yu, D.J.; Anderies, J.M.; Lee, D.; Perez, I. Transformation of resource management institutions under globalization: The case of Songgye community forests in South Korea. Ecol. Soc. 2014, 19, 2. [CrossRef]

40. Kang, S.-B. The practice of Songgye on the villages around Guksa-bong, Gyeryongsan-Focus on the Songgye of Hyanghan-ri, Gyeryong-shi. Korean J. Folk Stud. 2009, 24, 97-121. (In Korean) 
41. Yu, D.; Zhou, L.; Zhou, W.; Ding, H.; Wang, Q.; Wang, Y.; Wu, X.; Dai, L. Forest management in Northeast China: History, problems, and challenges. Environ. Manag. 2011, 48, 1122-1135. [CrossRef] [PubMed]

42. Gao, H.; Ouyang, Z.; Chen, S.; Koppen, C.S.A. Role of culturally protected forests in biodiversity conservation in Southeast China. Biodivers. Conserv. 2013, 22, 531-544. [CrossRef]

43. State Forestry Administration. National Report on Sustainable Forest Management; China Forestry Publishing House: Beijing, China, 2013; pp. 175-210.

44. He, J.; Zhou, Z.; Weyerhaeuser, H.; Xu, J. Participatory technology development for incorporating non-timber forest products into forest restoration in Yunnan, Southwest China. For. Ecol. Manag. 2009, 257, 2010-2016. [CrossRef]

45. He, J.; Sikor, T. Looking beyond tenure in China's collective forest tenure reform: Insights from Yunnan Province, Southwest China. Int. For. Rev. 2017, 19, 29-41. [CrossRef]

46. Liang, L.; Shen, L.; Yang, W.; Yang, X.; Zhang, Y. Building on traditional shifting cultivation for rotational agroforestry experiences from Yunnan, China. For. Ecol. Manag. 2009, 257, 1989-1994. [CrossRef]

47. The Forest Law of the People's Republic of China; Democracy and Law of China Press: Beijing, China, 2008; ISBN 9787802192225. (In Chinese)

48. Liu, J.; Innes, J.L. Participatory forest management in China: Key challenges and ways forward. Int. For. Rev. 2015, 17, 477-484. [CrossRef]

49. Ichikawa, K.; Okubo, N.; Okubo, S.; Takeuchi, K. Transition of the Satoyama landscape in the urban fringe of the Tokyo metropolitan area from 1880 to 2001. Landsc. Urban Plan. 2006, 78, 398-410. [CrossRef]

50. Igarashi, T.; Masaki, T.; Nagaike, T.; Tanaka, H. Species richness of the understory woody vegetation in Japanese cedar plantations declines with increasing number of rotations. J. For. Res. 2016, 21, 291-299. [CrossRef]

51. Yiu, E. Noto peninsula after GIAHS designation: Conservation and revitalization efforts of Noto's satoyama and satoumi. J. Resour. Ecol. 2014, 5, 364-369. [CrossRef]

52. Yao, Z.; Xin, Z.-J.; Wu, Y.-M.; You, H.L. Environmental management mode of satoyama in Japan and its enlightenment to construction of new country-side in China. J. Ecol. Rural Environ. 2017, 33, 769-774. (In Chinese)

53. Terada, T.; Yokohari, M.; Bolthouse, J.; Tanaka, N. "Refueling” satoyama woodland restoration in Japan: Enhancing restoration practice and experiences through woodfuel utilization. Nat. Cult. 2010, 5, 251-276. [CrossRef]

54. Katoh, K.; Sakai, S.; Takahashi, T. Factors maintaining species diversity in Satoyama, a traditional agricultural landscape of Japan. Biol. Conserv. 2009, 142, 1930-1936. [CrossRef]

55. Fujiwara, A.; Washitani, I. Dependence of Asian honeybee on deciduous woody plants for pollen resource during spring to mid-summer in northern Japan. Entomol. Sci. 2017, 20, 96-99. [CrossRef]

56. Kobayashi, S.; Abe, S.; Matsuki, R. Genetic structure of a Japanese brown frog (Rana japonica) population implies severe restriction of gene flow caused by recent urbanization in a Satoyama landscape. Mitochondrial DNA 2013, 24, 697-704. [CrossRef] [PubMed]

57. Lee, K.-J. Saemaul Undong and Foreset Rehabilitation in Korea: Saemaul Income Boosting Project and the Role of the Village Forestry Cooperative; Ministry of Strategy and Finance: Sejong, Korea, 2013; pp. 315-328. (In Korean)

58. Korea Forest Service. Lessons Learned from the Republic of Korea's National Reforestation Programme; Korea Forest Service: Daegu, Korea, 2014; pp. 1-42, ISBN 92-9225-579-7.

59. Choe, B.-T. The developments and character of setting up the forestry mutual-aid society in 1945 1960s. Sahak Yonku 2008, 90, 291-336. (In Korean)

60. Park, M.S.; Lee, H. Legal opportunities for public participation in forest management in the Republic of Korea. Sustainability 2016, 8, 369. [CrossRef]

61. Lee, J.; Lim, C.-H.; Kim, G.S.; Markandya, A.; Chowdhury, S.; Kim, S.J.; Lee, W.-K.; Son, Y. Economic viability of the national-scale forestation program: The case of success in the Republic of Korea. Ecosyst. Serv. 2018, 29, 40-46. [CrossRef]

62. Korea Forest Service. Restoration Cases of the Traditional Maeulsoop; Korea Forest Service: Daegu, Korea, 2015; pp. 1-171. (In Korean)

63. Lee, E.; Krasny, M.E. The role of social learning for social-ecological systems in Korean village groves restoration. Ecol. Soc. 2015, 20, 42. [CrossRef] 
64. Liu, J.; Liu, X. Transforming nomadic traditions to biodiversity-friendly livelihoods from the perspective of traditional forest-related knowledge: The successful story of $\mathrm{H}$ village of Yunnan Province in China. In Satoyama Initiative Thematic Review Volume 2; Ichikawa, K., Subramanian, S.M., Chakraborty, S., Eds.; United Nations University Institute for the Advanced Study of Sustainability: Tokyo, Japan, 2016; pp. 13-25, ISBN 978-92-808-4573-0.

65. He, J.; Xu, J. Is there decentralization in North Korea? Evidence and lessons from the sloping land management program 2004-2014. Land Use Policy 2017, 61, 113-125. [CrossRef]

66. Koike, O. Rehabilitation, conservation, and utilization of satoyama ecosystems and human well-being: A case of Kanagawa Prefecture in Japan. Yokohama J. Soc. Sci. 2017, 22, 41-54.

67. Fuchigami, Y.; Hara, K.; Uwasu, M.; Kurimoto, S. Analysis of the mechanism hindering sustainable forestry operations: A case study of Japanese forest management. Forests 2016, 7, 182. [CrossRef]

(C) 2017 by the authors. Licensee MDPI, Basel, Switzerland. This article is an open access article distributed under the terms and conditions of the Creative Commons Attribution (CC BY) license (http://creativecommons.org/licenses/by/4.0/). 